\title{
EFFECTS OF LEAVE AND BARK ASH OF AZADIRACHTA INDICA EXTRACTS AGAINST INSECT PEST OF AMARANTHUS HYBRIDUS L
}

\author{
Samuel Femi BABATUNDE ${ }^{1 *}$; Stephen Taiye. OGUNLEYE ${ }^{1}$; Aminat Arinola SOLIHU ${ }^{1}$ \\ ${ }^{1}$ Department of Crop Protection, Faculty of Agriculture, \\ University of Ilorin, Ilorin, Kwara State, Nigeria. \\ *Corresponding author
}

DOI: 10.46609/IJAER.2020.v06i03.013 URL: https://doi.org/10.46609/IJAER.2020.v06i03.013

\begin{abstract}
A field study was carried out to assess the efficacy of some botanicals in the control of field insect pests of Amaranthus hybridus. Dry leaf and bark ash extract of Azadirachta indica served as treatments which were compared with Lambdacyhalothrin and a control. The experiment was fitted into a randomized complete block design with three replications. Data collected were subjected to a two-way analysis of variance and significant different means were separated using Fishers Least Significant Difference (LSD) test at $5 \%$ level of probability. The results revealed that treated plants generally performed better than the untreated plants as they were taller, had more leaves, branches, wider stem girths and gave higher fruit yield. bark ash extract of Azadirachta indica performed better in most parameters measured. The results indicate that leaf and bark ash extract of Azadirachta indica if properly harnessed can be used as a biopesticide in the control of field insect pest of $A$. hybridus.
\end{abstract}

Keywords: Botanicals; Amaranthus hybridus; Azadirachta indica; Hymenia recurvalis

\section{INTRODUCTION}

Amaranthus hybridus is generally considered a weed in North America, commonly known as smooth amaranth, but is consumed as a staple food in other areas of the world such as Africa, Asia, the Caribbean and part of Europe (Abbasi et al., 2013). With an increasing immigrant population in Canada, the demand for A. hybridus has grown (Filson \& Adekulne, 2017).

The role of Amaranthus as an under-exploited plant with promising economic value was recognized by the National Academy of Sciences, USA (NAS, 1975), after which it's nutritional value has been extensively studied (Petr et al., 2003). 
International Journal of Agriculture and Environmental Research

ISSN: 2455-6939

Volume: 06, Issue: 03 "May-June 2020"

Martirosyan et al. [7], stated that regular consumption of amaranth reduces blood pressure, cholesterol levels and improves the body's antioxidant status and immunity. A. hybridus is recommended as a good food with medicinal properties for young children, lactating mothers and for patients with fever, anemia or kidney complaints.

Every part of A. hybridus, be it the leaves, stem, buds, flowers, fruits and seeds are a source of food for a wide range of pests resulting in reduced yield. Aderolu et al.

Amaranthus leaves show significant energy value ranging from 27 to $53 \mathrm{kcal} / 100 \mathrm{~g}$ of fresh leaves and high nutrient value ranging from 4 to $6 \mathrm{~g}$ of protein, 0.2 to $0.6 \mathrm{~g}$ of fat, and 4 to $7 \mathrm{~g}$ of carbohydrates per $100 \mathrm{~g}$ of fresh leaves (Uusikua et al., 2010) and are known to be rich in micronutrients and vitamins particularly chlorine, copper, iron, manganese, sodium, vitamin A, vitamin C and vitamin B-12 (Mnkeni, 2005).

Amaranthus leaves taste much like spinach but, are nutritionally superior as they contain 3 times more vitamin C, calcium and niacin than spinach (Mnkeni, 2005).

As compared to lettuce, Amaranthus leaves contain 18 times more vitamin A, 13 times more vitamin C, 20 times more calcium and 7 times more iron (Mnkeni, 2005; Srivastava, 2011).

Amaranthus seeds have protein content of about 12.5 to $17.6 \%$ (Becker et al., 1981; Teutonico \& Knorr, 1985), with significantly higher content of lysine $(0.73$ to $0.84 \%$ of the total protein content) and the sulphur-containing amino acids (methionine and cysteine) than other cereal grains (Becker et al., 1981; Saunders \& Becker, 1984;Railey, 1993; Lehmann, 1996; Petr et al., 2003) except soybeans (Petr et al. 2003), thus having potential to improve world food situation as an alternative source of protein (Oliveira \& de Carvalho, 1975).

According to Oerke and Dehne [9], pests contribute 30-40\% of crop loss worldwide while the loss in the tropics is reported to be even higher than $40 \%$.

\section{EXPERIMENTAL SITE}

The experimental site was located behind the Faculty of Agriculture Screenhouse, University of llorin, Kwara State, Nigeria, located in the southern Guinea Savannah agro-ecological zone of Nigeria between latitude $8^{\circ} 25^{\prime} \mathrm{N}$ and longitude $4^{\circ} 67^{\prime} \mathrm{E}$. The experiment was carried out between October and November 2017. The dry spell is experienced in August of every year. The site has an average temperature of $35^{\circ} \mathrm{C}$ and is characterized by sandy loam soil.

\section{SOURCES OF MATERIALS}


The seeds of A. hybridus used in this study were obtained from Agro mall Ilorin, Kwara State, Nigeria. The leaves and bark ashe of Azadirachta indica were sourced from the University of Ilorin premises.

\section{Field preparation and layout of experimental plot}

The land was cleared manually and mapped out into three blocks which represent the replicates. Each block was divided into four plots measuring $2 \mathrm{~m} \times 2.5 \mathrm{~m}$ each and raised as beds. A pinch of A. hybridus seeds were sown directly into the beds at a depth of $2 \mathrm{~cm}$ and sowing spacing of $30 \mathrm{~cm} \times 50 \mathrm{~cm}$ apart. After germination, the seedlings were thinned down to one seedling per hole. The plots were properly labeled based on the treatments.

\section{Experiment design and treatments}

The experiment was laid in a randomized complete block design and replicated thrice. The aqueous leaf and bark ash of A. indica extract were the treatments. The control was also included, which represent plants that were not sprayed with any extract and Lambdacyhalothrin as standard check. Thus, a total of four treatments were used.

\section{Preparation of aqueous extract and treatment application}

These plant parts were harvested and washed to remove dirt and sand particles and air dried separately in the shade for three (3) weeks, the bark were burn into ashes while the leaves were ground using a kitchen size electric blender. They were further sieved using a sieve of $2 \mathrm{~mm}$ mesh to obtain a uniform powder. lambda-cyhalothrin were used as standard check; and there was untreated control.

Plant extracts were prepared by maceration. $50 \mathrm{~g}$ of each powder were measured into a litre of water and allowed to stand for twenty-four hours while shaking from time to time to ease extraction. The resulting suspension was filtered using muslin cloth, and the filtrate was made up to 2 litres by adding distilled water. Lambdacyhalothrin $2.5 \%$ emulsifiable concentrate was used as a standard check at $0.5 \mathrm{~g}$ per litre. The extracts were sprayed on the plants of their respective plots at 7.00 am twice weekly, Mondays and Saturdays from 10 to 38 days after sowing (DAS).

\section{DATA ANALYSIS}

Data collected were subjected to a two-way analysis of variance (ANOVA) using Genstat 17th edition, and significantly different means were separated using Fishers Least Significant Difference (LSD) test at $5 \%$ level of significance. 
International Journal of Agriculture and Environmental Research

ISSN: 2455-6939

Volume: 06, Issue: 03 "May-June 2020"

Data were collected on total number of leaves, number of damaged leaves, percentage leaf damage, plant height, stem girth, and dry weight. Five leaves were randomly selected and tagged and used for these measurements. The number of leaves produced per A. hybridus plant for each of the treatments was counted and the mean number recorded. The number of leaves with holes created as a result of insect infestation was also counted and the mean recorded as the number of damaged leaves. The percentage leaf damaged was calculated as:

$$
\% \text { leaf damage }=\frac{\text { no of damage leaves }}{\text { number of leaves per plant }} \times 100
$$

The above measurements were done at weekly interval from 10-38 DAS. Total leaf number, leaf damage, plant height, stem girth and dry weight of the plant were determined at 38 DAS. Leaf area damage was determined by determining the area of the holes created on the leaves and summing them up. The stem girth was measured with a micro meter screw gauge; plant height was measured with a meter rule from the base of the stem at soil level to the terminal bud of the main stem, while for the root length, the plants were carefully uprooted and the length measured with a meter rule from the base of the stem at soil level to the tip of the root. The uprooted plants were dipped in a bucket of water to wash off the soil particles adhering to the roots. The water was allowed to drain and thereafter, the uprooted plants were chopped into pieces, packed in an envelope and dried in an oven at a temperature of $80^{\circ} \mathrm{C}$ until a constant weight was achieved. It was then weighed using an electronic balance and the mean weight recorded as the dry weight.

\section{RESULTS}

Total number of leaves produced per A. hybridus plant sprayed with aqueous leaf and bark ash extract of A. indica did not vary significantly from each other and from the control in all the sampled days except on 38 DAS (Table 1). total number of leaves produced by plants sprayed with the leaf extracts did not vary significantly. However, significant variation $(\mathrm{P}<0.05)$ existed among the treatments in the number of damaged leaves in all the days sampled (Table 1). Plants sprayed with leaf and bark ashe of $A$. indica had comparable number of damaged leaves with those sprayed with Lambdacyhalothrin but significantly lower number of damaged leaves than the control at 17, 24 and 31 DAS (Table 1). At 38 DAS, plants sprayed with dry leaves of $A$. indica had number of damaged leaves that did not differ significantly from those of bark ash of A. indica but was significantly lower than those sprayed with the control. The lowest percentage leaf damage was recorded in plants sprayed with Lambdacyhalothrin followed by bark ash of $A$. indica; this was closely followed by those sprayed with leaf of $A$. indica and the highest was recorded in the control plants 
Significant differences $(\mathrm{P}<0.05)$ were found among the treatments in the growth parameters assessed with the exception of the stem girth (Table 2). Plants sprayed with Lambdacyhalothrin had significantly the highest plant height, root length and dry weight while plants sprayed with the plant extracts had comparable values with the control plants.

The results showed that the aqueous plant extracts exhibited some level of control of the field pests of A. hybridus as they recorded lower percentage leaf damage in relation to the control. Decrease in percentage leaf damage to the application of the plant extracts is an indication of reduced number of foliage pests of A. hybridus. It is also an indication that the extracts possess insecticidal effects in reducing insect attack. the result in this experiment conform with the reports of Aderolu et al. [8], who reported decrease in insect population and number of damaged leaves of Amaranth sprayed with neem extracts.

However, the number of damaged leaves and the percentages of damaged leaf were consistently lower in plants sprayed with leaf extract of Lambdacyhalothrin when compared with the plant extracts. The percentage leaf damage followed this order: Lambdacyhalothrin was less than bark ash of $A$. indica while leaf extract of $A$. indica was less than the control. This result shows that plant extract of $A$. indica had greater pesticidal effect. Hamd et al. [18], reported the effectiveness of neem extract against aphid predator field pest. The leaf and seed extracts of the neem tree Azadirachta indica A. Juss have been shown to affect over 200 insect species including some species of aphids, beetles, caterpillars, leaf miners, mealybugs, scales, thrips, true bugs and whiteflies and is also the most popular botanical pesticide against foliage feeding pests

The linear response observed in the control on percentage leaf damage as the plant aged signifies continues feeding of foliage pests on A. hybridus leaves. This also connotes increase in pest population and goes further to support the effectiveness of the plant extracts used in the control of insect field pests of A. hybridus. Plants sprayed with neem extract showed more or less a static response in percentage leaf damage as the plant aged. This clearly shows the protective effect of neem extract against the foliage pests of A. hybridus. This agrees with the earlier report of Aderolu et al. [8]. 
International Journal of Agriculture and Environmental Research

ISSN: 2455-6939

Volume: 06, Issue: 03 "May-June 2020"

\section{Table 1: Effects of dry leaf and bark ash of Azadirachta indica extracts on total number of leaves and damaged leaves of $\mathrm{A}$. hybridus at different sampled days.}

\begin{tabular}{|l|l|l|l|l|l|l|l|l|}
\hline Treatment & \multicolumn{3}{l}{ 17DAS } & 24DAS & \multicolumn{3}{l|}{ 31DAS } & \multicolumn{2}{l|}{ 38DAS } \\
\hline & NL & NDL & NL & NDL & NL & NDL & NL & NDL \\
\hline control & 10 & 5.3 & 11.9 & 7.8 & 14.2 & 8.6 & 15.8 & 10.8 \\
\hline A. indica leaf & 9 & 3 & 11.5 & 4.2 & 13.6 & 4.9 & 15.2 & 5.3 \\
\hline A. indica bark ash & 7 & 2.4 & 9.9 & 4.5 & 14.5 & 5 & 17.6 & 6.3 \\
\hline Lambdacyhalothrin & 10 & 1 & 11.5 & 2.4 & 15 & 5.3 & 17.9 & 7.6 \\
\hline LSD & NS & 1.2 & NS & 1.9 & NS & 2.1 & 4.2 & 2.4 \\
\hline
\end{tabular}

$\mathrm{DAS}=$ days after sowing; $\mathrm{NL}=$ Number of leaves; $\mathrm{NDL}=$ number of damaged leaves.

\begin{tabular}{|l|l|l|l|l|}
\hline \multicolumn{5}{|c|}{ Table 2: Effect of treatments on growth parameters of A. hybridus. } \\
\hline Treatment & $\begin{array}{l}\text { plant } \\
\text { height }(\mathbf{c m})\end{array}$ & $\begin{array}{l}\text { stem } \\
\text { girth(cm) }\end{array}$ & $\begin{array}{l}\text { Dry } \\
\text { weight }(\mathbf{c m})\end{array}$ & Root length(cm) \\
\hline control & 28.5 & 30.6 & 6.9 & 28.3 \\
\hline A. indical leaf & 29.4 & 26.8 & 7.7 & 25.1 \\
\hline A. indical bark & 29.8 & 26.3 & 8.2 & 24.9 \\
\hline Lamda & 36.3 & 45.1 & 14.3 & 40 \\
\hline LSD & 6.4 & 6.7 & 5.9 & 6.4 \\
\hline
\end{tabular}

\section{CONCLUSION}

It was observation that none of the extracts used in this study produced any phytotoxic effect; neither leaf-yellowing nor shedding was observed. In addition, none of the plant extracts used inhibited growth. These go to support their use as suitable biopesticides. The results of this study showed that the aqueous leaf and bark ash extracts of the plant extracts used had pesticidal attribute on insect field pests of A. hybridus. A. it is recommend that A. indica can provide suitable alternative for pest control of vegetable crops like A. hybridus and can form the basis for a successful commercialization of bio-pesticide. 
International Journal of Agriculture and Environmental Research

ISSN: 2455-6939

Volume: 06, Issue: 03 "May-June 2020"

\section{REFERENCES}

Abbasi, A. M., Khan, M. A., Shah, M. H., Shah, M. M., Pervez, A., \& Ahmad, M. 2013. Ethnobotanical appraisal and cultural values of medicinally important wild edible vegetables of Lesser Himalayas-Pakistan. Journal of Ethnobiology and Ethnomedicine, 9: 66.

Aderolu IA, Omooloye AA, Okelana FA. 2013. Occurrence, abundance and control of the major insect pests associated with amaranths in Ibadan, Nigeria. Entomol Ornithol Herpetol. 2: 112-120.

Becker, R., E. L.Wheeler, K. Lorenz, A. E. Stafford, O. K. Grosjean, A. A. Betschart \& R.M. Saunders. 1981. A composition study of amaranth grain. Journal of Food Science 46: $1175-1180$.

Ebert AW, Wu T, Wang S. 2011. International cooperators' guide-vegetable amaranth (Amaranthus L.). AVRDC Publication no.11-754. Taiwan: Asian Vegetable Research and Development Center.

Filson, G. C., \& Adekunle, B. 2017. Eat Local, Taste Global: How Ethnocultural Food Reaches Our Tables. Wilfrid Laurier University Press. 280.

Lehmann, J. W. 1996. Case history of grain Amaranthus and alternative crop. Cereal Foods World 41: 399-411.

Mnkeni, A. P. 2005. The underutilized plant with high nutritional quality and economic potential. Agricultural and Rural Development Research Institute, Newsletter, University of Fort Hare. July to December 2005.

National Academy of Sciences. 1975. Underexploited tropical plants with promising economic value. National Academy of Sciences, Washington, DC.

Okpako EC, Osuagwu AN, Agbor RB, et al. 2013. Repellance effect of aqueous extract of alligator pepper (Aframomum melegueta K. Schum) on insects of okra. World Rural Observations. 5: 42-46.

Oliveira, J. S. \& M. F. de Carvalho. 1975. Nutritional value of some edible leaves used in Mozambique. Economic Botany 29: 255-263. 
Petr, J., I. Michalik, H. Tlaskalova, I. Capouchova, O. Famera, D. Urminska, L. Tukova \& H. Knoblochova. 2003. Extension of the spectra of plant products for the diet in celiac disease. Czech journal of food sciences 21: 59-70.

Railey, K. 1993. Amaranth: A healthy grain for vegetarian recipes. Health \& Beyond Online

Saunders, R. M. \& R. Becker. 1984. Amaranthus: A potential food and feed resource. Advances in Cereal Science and Technology 6: 357-396.

Srivastava, R. 2011. Nutritional quality of some cultivated and wild species of Amaranthus L. International Journal of Phamaceutical Science and Research 2: 3152-3156.

Teutonico, R. A. \& D. Knorr. 1985. Amaranth: Composition, properties, and applications of a rediscovered food crop. Food technology 39: 49-60.

Uusikua, N. P., A. Oelofsea, K. G. Duodub, M. J. Besterc \& M. Faberd. 2010. Nutritional value of leafy vegetables of sub-Saharan Africa and their potential contribution to human health: A review. In: Journal of Food Composition and Analysis 23: 499-509. 